\title{
MAPEAMENTO DE AQÜÍFEROS NA CIDADE DE MANAUS (AM) - UTILIZANDO PERFILAGEM GEOFÍSICA DE POÇO E SONDAGEM ELÉTRICA VERTICAL
}

\author{
Lena Simone Barata Souza \\ Orientador: Dr. Om Prakash Verma (UFPA) \\ 85 p. - Dissertação (Mestrado) - Defesa 28.09.2005
}

RESUMO. 0 sistema de águas subterrâneas vigentes na cidade de Manaus (AM) é pertencente ao Aqǘfero Alter do Chão, 0 qual é caracterizado por fácies sedimentares arenosa, argilosa, areno-argilosa e "Arenito Manaus" depositadas em ambiente fluvial e flúvio-deltáico. Estima-se que $32.500 \mathrm{~km}^{3}$ de água possam ser explorados, fornecendo poços confinados a semiconfinados com vazão de até $300 \mathrm{~m}^{3} / \mathrm{h}$ em poços de aproximadamente $220 \mathrm{~m}$ de profundidade. Grandes distorções, contudo, têm sido notadas, Manaus, em foco neste trabalho, tem poços com baixo rendimento (de $78 \mathrm{~m}^{3} / \mathrm{h}$ ), devido à má colocação de filtros em consequiência da falta de informações sobre os aqüíferos. Através do uso integrado de perfilagem geofísica de poço (perfis de raio gama, de potencial espontâneo e de resistência elétrica), sondagem elétrica vertical e informações litológicas de amostragem de calha, mapearam-se camadas litológicas permo-porosas com elevado potencial aqǘfero nas zonas norte e leste da cidade de Manaus. Foram identificadas duas zonas aquíferas. A primeira zona é marcada pelos $50 \mathrm{~m}$ iniciais de profundidade. Nesta zona distinguem-se três tipos de litologias: argilosa, arenosa e areno-argilosa com as mais variadas dimensões. Estas duas últimas litologias apresentam elevado potencial aqüífero. Mesmo assim, nesta zona não há tendência a conter um volume de água considerável, devido à limitada continuidade lateral dos corpos arenosos e estar sujeita aos estorvos antrópicos superficiais. Portanto, não indicada para explotação de água em grandes quantidades. A segunda zona se estende a partir dos $50 \mathrm{~m}$ até aproximadamente $290 \mathrm{~m}$ de profundidade. É caracterizada por dois tipos de litologias: arenosa e areno-argilosa. Ao contrário da primeira, a esta profundidade há propensão do armazenamento e exploração de água. Apresenta litologias com elevado potencial aqüífero, cujos corpos arenosos são mais espessos e possuem uma maior continuidade lateral que os da zona 1 ; e valores de vaza o de quase $300 \mathrm{~m}^{3}$. Serve, então, para abastecimento público por causa das boas vazões, garantia de água de boa qualidade protegida de ações antrópicas. cujos corpos arenosos são mais espessos e possuem uma maior continuidade lateral que os da zona 1 ; e valores de vaza 0 de quase $300 \mathrm{~m}^{3}$. A análise feita quanto à variação lateral, em mapas, de resistência transversal e condutância longitudinal, revelou que nas porções inferiores a $50 \mathrm{~m}$ de profundidade os setores NE e SW correspondem às zonas permeáveis. Portanto, possuem menos faixas argilosas, sendo considerados os setores mais transmissivos do sistema aqǘfero. Os poços com profundidade maiores que $50 \mathrm{~m}$ recomenda-se sua locações nas faixas NNW, SW e extremo sul, em virtude dos resultados obtidos através da perfilagens geofísicas de poços, as quais delineiam camadas permo-porosas de elevado potencial aqüífero para a área estudada.

ABSTRACT. The principal source of groundwater in Manaus-AM is the Alter of Chão aquifer. This aquifer is characterized by sand, clay and sandyclay sedimentary facies and the Manaus sandstones, deposited in the fluvial and fluvial-deltaic ambient. An estimated amount of $32.500 \mathrm{~km}^{3}$ of groundwater can be exploited from this aquifer through wells of about $220 \mathrm{~m}$ deep, producing water at a maximum rate of $300 \mathrm{~m}^{3} / \mathrm{h}$. However, there are big distortions in the production rates. In some boreholes they are as low as $78 \mathrm{~m}^{3} / \mathrm{h}$ because of wrong filter locations due to the lack of information about the aquifer position in depth. The permo-porous zones forming the aquifers were mapped in the northern and eastern part of the town of Manaus, employing in integration of the information available from the well-log geophysical data, Vertical Electrical Sounding (VES) data the litology obtained through the examination of the borehole cuttings. This work resulted in the identification of two distinct geohydrological zones in depth. The first, up to the depth of $50 \mathrm{~m}$, is marked by clay, sand and sandy-clay zones of varied dimensions. However, they are not recommended for great demand of water because of the limited lateral extension of the sand zones and for being susceptible to superficial contaminations. The second zone extents below $50 \mathrm{~m}$ to about $290 \mathrm{~m}$ in depth, and is very appropriate for the storage of large amount of groundwater because it contains thick sand zones of great lateral extensions. The production rate of the wells in this aquifer is around $300 \mathrm{~m}^{3} / \mathrm{h}$. Therefore, it is recommended for the supply of good quality groundwater to meet higher demands such as for a district in a town. An analysis of the transverse resistance and longitudinal conductance maps of the upper zone up to $50 \mathrm{~m}$, leads to that NE and SW sectors of the area contend more permeable zones, contend less clayey layers, therefore, of higher transmissibility zones of the aquifer system. However, for wells deeper than $50 \mathrm{~m}$, recommend NNW e SW region for their locations based on the results obtained through Geophysical Well Logging that delineates the permo-pourous layers forming a good aquifer. 